\title{
PENGARUH SUHU DAN WAKTU PENGARANGAN TERHADAP KUALITAS BRIKET ARANG DARI LIMBAH TEMPURUNG KELAPA SAWIT
}

\section{The Effect of Carbonization Temperature and Carbonization Time on The Quality of Charcoal Briquette from Oil Palm Shell Waste}

\author{
Djoko Purwanto*1 dan Sofyan ${ }^{2}$ \\ 1 Baristand Industri Banjarbaru Jl. Panglima Batur Barat No.2 Banjarbaru 70711 \\ 2 Baristand Industri Padang JI. Raya LIK No. 23 Ulu Gadut Padang 25164 \\ *e-mail : baristand.banjarbaru@gmail.com
}

Diterima: 20 Maret 2013, revisi akhir: 7 November 2013 dan disetujui untuk diterbitkan: 6 Mei 2014

\begin{abstract}
ABSTRAK
Limbah tempurung kelapa sawit merupakan limbah padat yang dihasilkan dari pengolahan kelapa sawit. Untuk meningkatkan nilai tambah, maka limbah ini dapat dimanfaatkan menjadi briket arang yang dapat digunakan sebagai salah satu sumber energi alternatif. Tujuan penelitian adalah untuk mendapatkan briket arang tempurung kelapa sawit yang secara teknis dapat memenuhi persyaratan kualitas bahan bakar. Perlakuan yang digunakan yaitu suhu pengarangan $\left(400^{\circ} \mathrm{C}, 500^{\circ} \mathrm{C}\right.$ dan $\left.600^{\circ} \mathrm{C}\right)$ dan waktu pengarangan $(2 \mathrm{jam}, 3 \mathrm{jam}$, dan $4 \mathrm{jam})$. Arang serbuk dicampur dengan perekat amylum $5 \%$ dan dicetak berbentuk silinder dengan diameter $3 \mathrm{~cm}$ dan tinggi $7 \mathrm{~cm}$. Briket yang dihasilkan dianalisis mutunya yang meliputi kadar air, kadar abu, kadar karbon, kadar zat terbang, kadar sulfur, nilai kalor, kerapatan dan kekuatan tekan. Berdasarkan hasil analisis dan pengolahan data diperoleh bahwa suhu dan waktu pengarangan berpengaruh sangat nyata terhadap kualitas briket arang. Briket arang yang terbaik ditinjau dari nilai kalornya diperoleh dari perlakuan suhu pengarangan $600^{\circ} \mathrm{C}$ dan waktu pengarangan 2 jam dengan karakteristik kadar air 2,92\%; kadar abu 5,83\%; kadar karbon $72,93 \%$; kadar zat terbang 18,31\%; kadar sulfur negatif; nilai kalor 7021,76 kal/g; kerapatan $0,97 \mathrm{~g} / \mathrm{cm}^{3}$ dan kekuatan tekan $7,08 \mathrm{~kg} / \mathrm{cm}^{2}$. Produk briket arang ini memenuhi syarat mutu briket arang kayu sesuai Standar Nasional Indonesia 01-6235-2000.
\end{abstract}

\section{Kata Kunci : Tempurung kelapa sawit, suhu pengarangan, waktu pengarangan, briket arang}

\begin{abstract}
Oil palm shell waste is a solid waste that is generated from processing of palm oil. This waste can be utilized as charcoal briquettes that can be used as an alternative energy to increase the added value. The research purpose to obtain charcoal briquettes of palm shell waste that technically meet requirement of fuel quality. The treatments of the research were carbonization temperature $\left(400^{\circ} \mathrm{C}, 500^{\circ} \mathrm{C}\right.$ and $600^{\circ} \mathrm{C}$ ) and carbonization time (2 hours, 3 hours, and 4 hours). The charcoal powder was mixed with adhesive amylum $5 \%$ and moulded in cylinder form with diameter $3 \mathrm{~cm}$ and height $7 \mathrm{~cm}$. The obtained briquettes was analyzed the quality consisted of water content, ash content, carbon content, volatile matter content, sulfur content, calorific value, density and compressive strength. Based on analysis result and data processing were found that carbonization temperature and time very significantly effected on the quality of charcoal briquettes. The best charcoal briquette in term of its calorific value was obtained from treatment of charcoal temperature $600^{\circ} \mathrm{C}$ and charcoal time 2 hours with characteristics of the water content $2.92 \%$, ash content $5.83 \%$, carbon content $7021.76 \mathrm{cal} / \mathrm{g}$, density $0.97 \mathrm{~g} / \mathrm{cm}^{3}$ and compressive strength $7.08 \mathrm{~kg} / \mathrm{cm}^{2}$. This charcoal briquettes met the quality requirement for wood charcoal briquette according to Indonesia National Standard 01-6235-2000.
\end{abstract}

Keywords: Oil palm shell, carbonization temperature, carbonization time, charcoal briquette 


\section{PENDAHULUAN}

Luas lahan perkebunan kelapa sawit di Indonesia pada tahun 2011 mencapai 8,992 juta hektar dan dapat menghasilkan kelapa sawit sekitar 23,096 juta ton (Direktorat Jenderal Perkebunan, 2012). Menurut Fauzi dan Satyawibawa (2002), pada proses pengolahan minyak kelapa sawit akan dihasilkan limbah padat berupa tempurung atau cangkang yang jumlahnya $60 \%$ dari produksi minyak inti sawit atau PKO (Palm Kernel Oil). Limbah padat tersebut saat ini belum dimanfaatkan secara optimal dan hanya digunakan sebagai bahan bakar pembangkit tenaga uap dan pengeras jalan (Purwanto, 2011).

Kebutuhan energi yang terus meningkat dan semakin terbatasnya energi fosil yang berasal dari minyak dan gas bumi memerlukan upaya-upaya untuk mencari energi dari sumber lain. Dengan potensi limbah tempurung kelapa sawit yang demikian besar, maka pemanfaatannya sebagai briket arang merupakan suatu alternatif pengganti energi yang berasal dari minyak dan gas. Tempurung kelapa sawit mempunyai karakteristik warna hitam keabuan, bentuk tidak beraturan dan memiliki kekerasan cukup tinggi.

Briket arang adalah serbuk arang yang dicampur perekat, dicetak dalam bentuk dan ukuran tertentu, kemudian dikeraskan melalui proses pengepresan, dan digunakan untuk bahan bakar. Kualitas briket arang yang terbuat dari kayu menurut Standar Nasional Indonesia 01-6235-2000 ditentukan oleh kadar air, bagian yang hilang pada pemanasan $900^{\circ} \mathrm{C}$, Kadar abu dan kalori (Badan Standardisasi Nasional, 2000).

Menurut Hendra dan Pari (2009), proses pembuatan briket arang kayu dapat dilakukan dengan arang digiling/ dihancurkan menjadi serbuk, disaring untuk memperoleh ukuran kehalusan, dicampur perekat (kanji), dimasukkan dalam cetakan, dikempa dengan sistim hidrolik, dan briket yang diperoleh dikeringkan. Keuntungan briket arang dibandingkan dengan arang diantaranya adalah lebih seragam, bentuknya rapi, bahan baku yang berukuran kecil memudahkan untuk penghancuran dan transportasi, dapat dibuat dari berbagai bahan dan ukuran.

Beberapa penelitian mengenai pembuatan briket arang dari limbah pertanian telah dilaporkan oleh beberapa peneliti dengan hasil yang berbeda-beda. Wijayanti (2009) melaporkan bahwa penambahan arang cangkang sawit dapat meningkatkan nilai kalor briket arang. Perbandingan campuran serbuk gergaji dan cangkang sawit sebesar 50\% : 50\% menghasilkan briket arang dengan nilai kalor $6117,67 \mathrm{kal} / \mathrm{g}$.

Martynis (2012) melaporkan bahwa biobriket dari limbah cangkang kakao dengan ukuran 30 mesh dapat menghasilkan nilai kalor lebih besar dari $4000 \mathrm{kal} / \mathrm{g}$. Nilai ini masih lebih kecil dari persyaratan nilai kalor menurut SNI 01-6325-2000 untuk arang kayu yaitu minimum $5.000 \mathrm{kal} / \mathrm{g}$. Yuliza dkk (2013) melakukan riset briket arang dari sekam padi dan kulit biji jarak dan diperoleh rata-rata nilai kadar abu, nilai kalor, volatile matter dan kerapatan belum memenuhi SNI 01-6325-2000, sedangkan rata-rata nilai kadar air, fixed carbon, dan kekuatan tekan memenuhi SNI 01-63252000.

Raharjo (2013) dalam riset pembuatan briket bioarang dari limbah abu ketel, jarak dan gliserin melaporkan bahwa dari perlakuan penelitian yang dilakukan diperoleh nilai kalor rata-rata tertinggi $3.383 \mathrm{kal} / \mathrm{g}$. Penelitian briket arang dari limbah arang PT. Citra Prima Utama Banjarbaru yang dilakukan oleh Mahdie (2010) diperoleh nilai kalor rata-rata dari semua perlakuan adalah $4995,061 \mathrm{kal} / \mathrm{g}$.

Dengan pemakaian tempurung kelapa sawit untuk briket arang diharapkan dapat diperoleh briket arang dengan nilai kalor dan sifat-sifat lainnya yang memenuhi persyaratan. Penelitian ini bertujuan membuat briket arang dari tempurung kelapa sawit dengan variasi suhu dan waktu pengarangan sehingga didapatkan briket arang yang secara teknis dapat memenuhi persyaratan kualitas bahan bakar. Persyaratan kualitas untuk briket arang tempurung kelapa sawit belum ada, sehingga untuk mengetahui kualitas briket arang yang dihasilkan, mengacu pada standar briket arang kayu SNI 01-62352000. 


\section{METODOLOGI PENELITIAN}

Bahan yang digunakan pada penelitian ini adalah limbah tempurung kelapa sawit yang diperoleh dari industri pengolahan kelapa sawit PT. Smart di Kabupaten Tanah Laut Jorong Kalimantan Selatan. Bahan penolong yang digunakan adalah perekat (kanji/amylum). Peralatan yang digunakan diantaranya tanur untuk proses pengarangan, penghancur arang, saringan, press hidrolik dan bomb calorimeter.

Prosedur kerja penelitian diawali dengan mengeringkan tempurung kelapa sawit secara alami hingga memiliki kadar air kering udara. Tempurung kelapa yang telah kering udara, selanjutnya dilakukan proses pengarangan dengan variasi perlakuan suhu pengarangan (A) yang meliputi $400^{\circ} \mathrm{C}$ (a1); $500^{\circ} \mathrm{C}$ (a2); dan $600^{\circ} \mathrm{C}$ (a3): serta waktu pengarangan (B) yang meliputi 2 jam (b1); 3 jam (b2); dan 4 jam (b3). Setiap perlakuan diulang sebanyak 3 kali. Arang yang diperoleh, dihancurkan dan disaring dengan kehalusan 7 mesh.

Arang serbuk kemudian dicampur dengan larutan kanji 5\%. Arang yang telah diberi perekat kemudian dicetak menggunakan cetakan berbentuk silinder dengan ukuran diameter $3 \mathrm{~cm}$ dan tinggi 7 $\mathrm{cm}$. Arang hasil cetakan dilakukan penekanan kempa $15 \mathrm{~kg} / \mathrm{cm}^{2}$ pada suhu $110^{\circ} \mathrm{C}$ selama 15 menit. Briket arang hasil cetakan dikeringkan secara alami hingga kering udara.

Briket arang yang telah dikeringkan diuji kadar air, abu, karbon, zat terbang, sulfur, nilai kalor, kerapatan dan kekuatan tekan. Pengujian kadar air, kadar abu, kadar karbon, kadar zat terbang, kadar sulfur, dan nilai kalor, berpedoman pada SNI. 13-34811994 (Badan Standardisasi Nasional, 1994); SNI. 01-6235-2000 (Badan Standardisasi Nasional, 2000); dan SNI. 13-3478-1994 (Badan Standardisasi Nasional, 1994). Pengujian kerapatan dan kekuatan tekan menggunakan metoda pengujian sifat fisik dan mekanik kayu (Nurwati, 2004). Tahapan penelitian pemanfaatan limbah tempurung kelapa sawit untuk briket arang dapat dilihat pada Gambar 1.

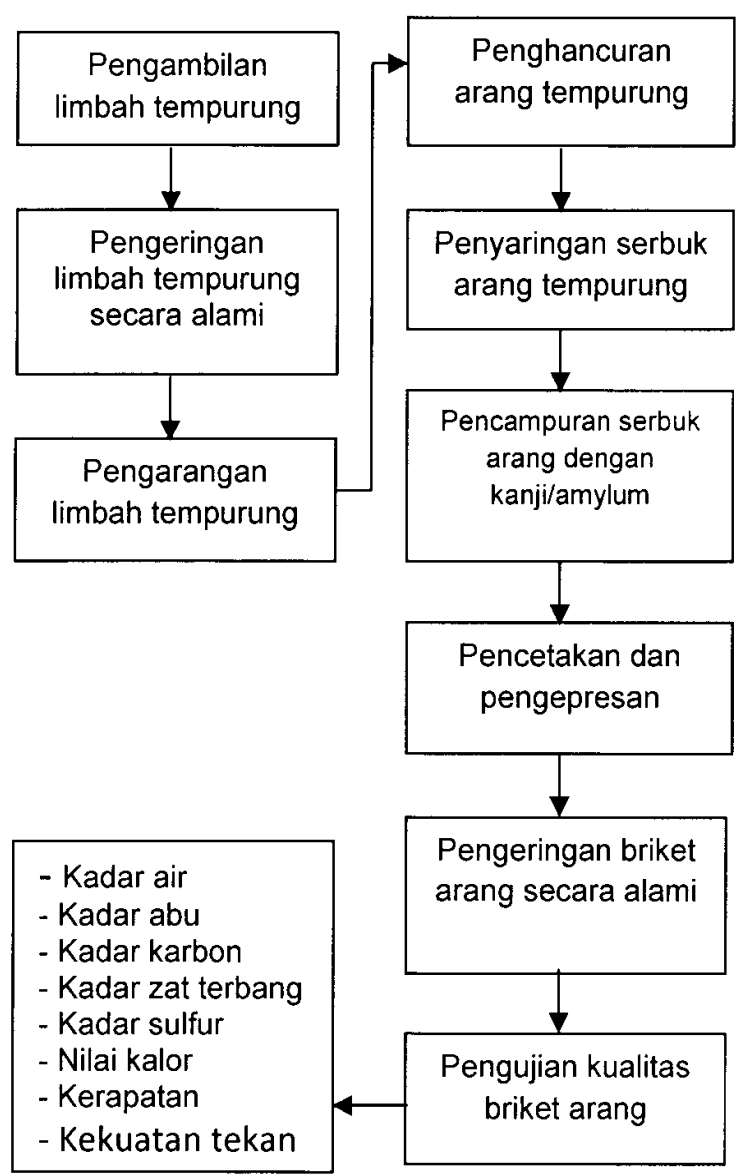

Gambar 1. Tahapan penelitian

Data penelitian diolah menggunakan Rancangan Acak Lengkap (RAL) faktorial, dengan model menurut Sudjana (1985) seperti pada persamaan 1 .

$$
\begin{aligned}
& Y_{i j k}=U+A_{i}+B_{j}+A B_{i j}+E_{i j k} \\
& U=\text { nilai rata-rata harapan } \\
& A_{i}=\text { pengaruh perlakuan } A \text { pada } \\
& \text { tingkat ke-i } \\
& \mathrm{B}_{\mathrm{j}}=\text { pengaruh perlakuan } \mathrm{B} \text { pada } \\
& \text { tingkat ke-j } \\
& A B_{i j}=\text { interaksi } A B \text { pada tingkat ke-i } \\
& \text { (A) tingkat ke- } \mathrm{j}(\mathrm{B}) \\
& E_{\mathrm{ijk}}=\text { kesalahan percobaan }
\end{aligned}
$$

Analisis lanjutan dilakukan terhadap analisis persamaan regresi dan uji beda nyata jujur (BNJ). Data analisis briket arang dari hasil percobaan juga dibandingkan dengan Standar Nasional Indonesia Nomor 01-6235-2000 untuk briket arang kayu. 


\section{HASIL DAN PEMBAHASAN}

\section{Kadar air}

Kadar air briket arang tempurung kelapa sawit yang dihasilkan berkisar antara 2,45-3,68\% seperti yang ditampilkan pada Tabel 1. Angka ini memenuhi sebagai bahan bakar karena bila dibandingkan dengan persyaratan kualitas kadar air briket arang kayu untuk bahan bakar sesuai SNI 016235-2000 yaitu maksimum 8\% . Persyaratan kadar air briket arang kayu buatan Jepang 6-8\%, Amerika 6,2\% dan Inggis 3,6\% (Hendra dan Winarni, 2003). Kadar air yang tertinggi $(3,68 \%)$ diperoleh dari tempurung kelapa sawit yang diarangkan pada suhu $500^{\circ} \mathrm{C}$ selama 2 jam dan kadar air yang terendah $(2,45 \%)$ dihasilkan oleh tempurung kelapa sawit yang diarangkan pada suhu $600^{\circ} \mathrm{C}$ selama 4 jam.

Dari perhitungan sidik ragam, semua perlakuan dan interaksinya berpengaruh sangat nyata terhadap kadar air. Berdasarkan uji regresi, ada kecenderungan makin tinggi suhu $\left(X_{1}\right)$ dan lama pengarangan $\left(X_{2}\right)$, maka kadar air makin rendah seperti pada Tabel 2. Kadar air juga sangat erat kaitannya dengan kerapatan briket arang, dimana semakin tinggi kerapatan maka sifat higroskopis briket arang semakin berkurang sehingga daya serap terhadap air akan semakin kecil, demikian pula sebaliknya. Hal ini disebabkan semakin tinggi kerapatan maka ronggarongga antar partikel arang akan semakin rapat karena padunya partikel-partikel tersebut sehingga tidak terdapat celah atau atau ruang kosong (Bahri, 2008).

Tabel 1. Hasil analisis kadar air, kadar abu dan kadar karbon

\begin{tabular}{|c|c|c|c|c|}
\hline \multirow{2}{*}{$\begin{array}{c}\text { Suhu } \\
\left({ }^{\circ} \mathrm{C}\right)\end{array}$} & \multirow{2}{*}{$\begin{array}{c}\text { Waktu } \\
(j a m)\end{array}$} & \multicolumn{3}{|c|}{ Hasil Analisis } \\
\cline { 3 - 5 } & & $\begin{array}{c}\text { Kadar air } \\
(\%)\end{array}$ & $\begin{array}{c}\text { Kadar abu } \\
(\%)\end{array}$ & $\begin{array}{c}\text { Kadar karbon } \\
(\%)\end{array}$ \\
\hline 400 & 2 & 2,69 & 5,50 & 58,61 \\
400 & 3 & 2,83 & 5,15 & 56,57 \\
400 & 4 & 3,26 & 5,46 & 52,24 \\
\hline 500 & 2 & 3,68 & 5,61 & 69,13 \\
500 & 3 & 3,31 & 5,32 & 69,50 \\
500 & 4 & 2,73 & 5,20 & 60,95 \\
\hline 600 & 2 & 2,92 & 5,83 & 72,93 \\
600 & 3 & 2,56 & 7,23 & 64,56 \\
600 & 4 & 2,45 & 7,40 & 69,23 \\
\hline
\end{tabular}

Tabel 2. Persamaan regresi hubungan antara suhu pengarangan $\left(X_{1}\right)$ dan waktu pengarangan $\left(\mathrm{X}_{2}\right)$ terhadap analisis briket arang

\begin{tabular}{|c|c|c|c|}
\hline Hasil analisa & Persamaan regresi & $\begin{array}{l}\text { Koefisien } \\
\text { korelasi }(r)\end{array}$ & F-hitung \\
\hline Kadar air (\%) & $Y=4,07-0,001 X_{1}-0,141 X_{2}$ & 0,185 & $0,68^{* \star}$ \\
\hline Kadar abu (\%) & $Y=1,67+0,007 X_{1}+0,186 X_{2}$ & 0,578 & $4,12^{\star \star}$ \\
\hline Kadar karbon (\%) & $Y=40,1+0,006 X_{1}-3,04 X_{2}$ & 0,792 & 11,40 ** \\
\hline Kadar zat terbang (\%) & $Y=-54,1-0,711 X_{1}+3,00 X_{2}$ & 0,817 & $13,42^{\star \star}$ \\
\hline Nilai kalor $(\mathrm{kal} / \mathrm{g})$ & $Y=60,30+1,86 X_{1}-154 X_{2}$ & 0,693 & $6,77^{\star \star}$ \\
\hline Kerapatan $\left(\mathrm{g} / \mathrm{cm}^{3}\right)$ & $Y=0,75+0,0004 X_{1}-0,002 X_{2}$ & 0,70 & $7,00^{\star *}$ \\
\hline Kekuatan Tekan $\left(\mathrm{kg} / \mathrm{cm}^{2}\right)$ & $Y=1,09+0,009 X_{1}-0,381 X_{2}$ & 0,57 & $3,98^{\star \star}$ \\
\hline
\end{tabular}

Keterangan : ${ }^{* *}$ sangat nyata

Menurut Nurhayati dan Adalina (2007), kadar air pada arang dipengaruhi oleh waktu pangarangan. Bahan baku briket arang yang memiliki kerapatan dan berat jenis rendah dapat lebih mudah menyerap udara dari sekelilingnya sehingga menyebabkan tingginya kadar air briket arang.

Hasil uji BNJ menunjukkan bahwa tidak semua perlakuan dan intereaksinya menyebabkan perbedaan yang nyata terhadap kadar air seperti terlihat pada Tabel 3. Sebagai contoh adalah perlakuan suhu pengarangan $600^{\circ} \mathrm{C}$ dengan waktu pengarangan 2 jam (a3b1) diperoleh kadar air sebesar $2,92 \%$ tidak memberikan perbedaan yang nyata terhadap kadar air yang dihasilkan pada suhu pengarangan $500^{\circ} \mathrm{C}$ dengan waktu pengarangan 4 jam (a2b3) sebesar 2,83\%. 
Tabel 3. Hasil uji BNJ (beda nyata jujur) briket arang tempurung kelapa sawit

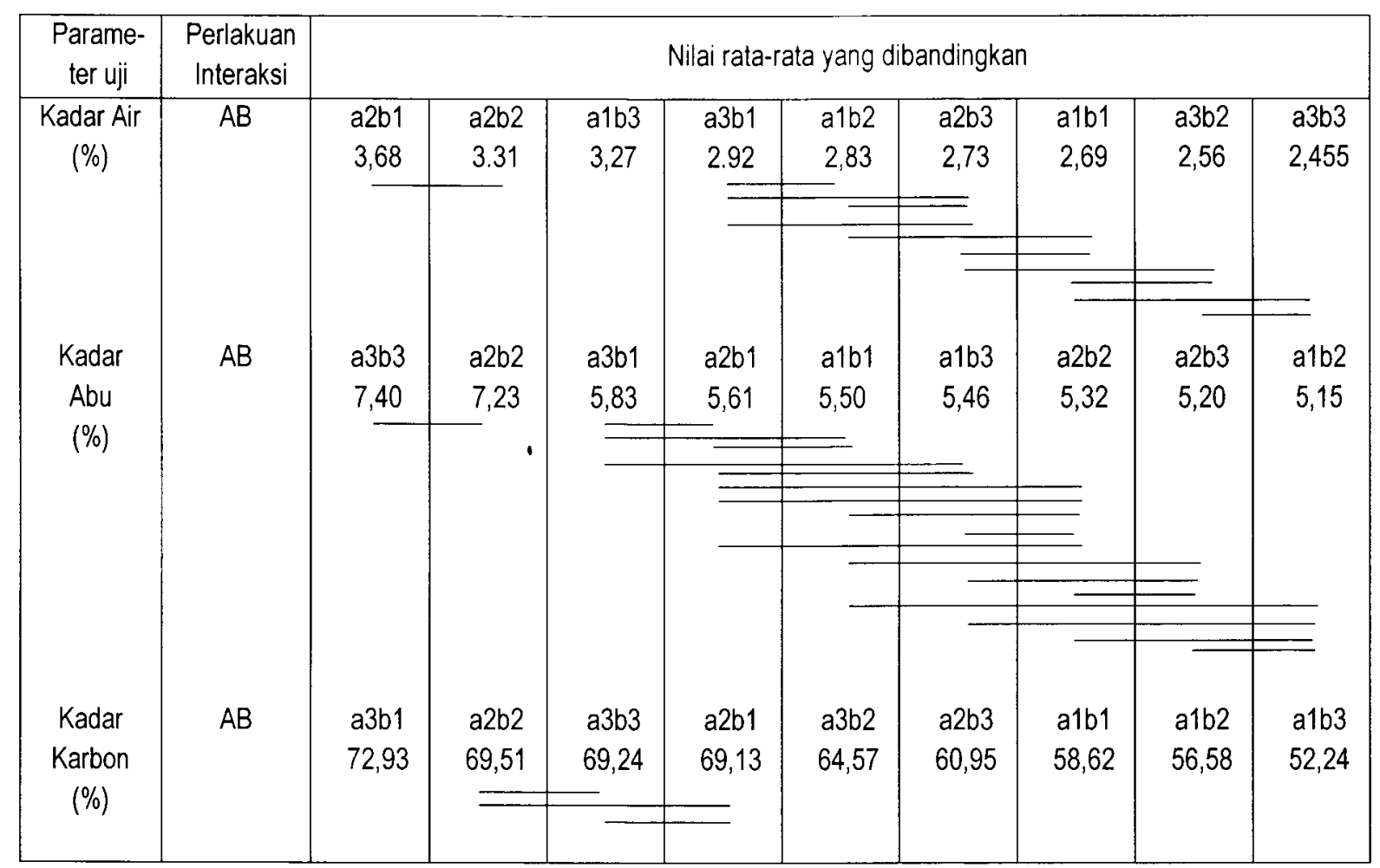

Keterangan: $\mathrm{AB}$ : Interaksi antara suhu dengan waktu pengarangan

Tidak berbeda nyata

\section{Kadar abu}

Kadar abu briket arang tempurung kelapa sawit yang dihasilkan berkisar antara $5,15-7,40 \%$ seperti pada Tabel 1 . Angka ini memenuhi persyaratan kadar abu briket arang kayu untuk bahan bakar sesuai SNI 01-6235-2000 yaitu maksimum 8\% dan lebih rendah bila dibandingkan dengan kualitas briket arang buatan Amerika (18\%) dan Inggis (8-10\%). Namun lebih besar dibandingkan kualitas briket arang buatan Jepang (3-6\%) (Hendra dan Winarni, 2003). Kadar abu briket arang tempurung kelapa sawit yang terendah $(5,15 \%)$ dihasilkan pada suhu pengarangan $400^{\circ} \mathrm{C}$ selama 3 jam, dan yang tertinggi $(7,40 \%)$ diperoleh pada tempurung kelapa sawit yang diarangkan pada suhu $600^{\circ} \mathrm{C}$ selama 4 jam.

Dari perhitungan sidik ragam semua perlakuan dan interaksinya berpengaruh sangat nyata terhadap kadar abu yang dihasilkan. Berdasarkan uji regresi seperti ditampilkan pada Tabel 2, ada kecenderungan makin tinggi suhu $\left(\mathrm{X}_{1}\right)$ dan lama pengarangan $\left(\mathrm{X}_{2}\right)$, maka kadar abu makin tinggi. Hal ini disebabkan karena partikel-partikel karbon yang terbakar menjadi abu makin bertambah. Hasil uji BNJ menunjukkan bahwa tidak semua perlakuan dan interaksinya memberikan perbedaan yang nyata terhadap kadar abu seperti yang ditampilkan pada Tabel 3. Sebagai contoh adalah suhu pengarangan $600^{\circ} \mathrm{C}$ dengan waktu pengarangan 4 jam (a3b3) sebesar $7,40 \%$ tidak memberikan perbedaan yang nyata terhadap kadar abu yang dihasilkan pada pengarangan $500^{\circ} \mathrm{C}$ dengan waktu pengarangan 5 jam (a2b2) sebesar $7,23 \%$.

Kadar abu pada briket arang dapat dipengaruhi diantaranya oleh banyaknya serabut/serat yang masih melekat pada tempurung kelapa sawit. Ditambahkan oleh Yuliza dkk (2013) bahwa kadar abu dapat disebabkan oleh komposisi bahan baku yang mengandung abu, serat, protein, lemak dan karbohidrat yang menjadi abu pada saat proses pengabuan. Menurut Martynis dkk (2012), kadar abu bisa juga disebabkan oleh pencampuran bahan 
perekat dan bahan baku yang tidak homogen sehingga pada proses pembakaran bahan perekat terbakar menjadi abu.

\section{Kadar karbon}

Kadar karbon briket arang tempurung kelapa sawit yang dihasilkan berkisar antara $52,24-72,93 \%$ seperti terlihat pada Tabel 1. Kadar karbon yang tertinggi (72,93\%) diperoleh pada suhu pengarangan $600^{\circ} \mathrm{C}$ dengan waktu pengarangan 2 jam. Nilai ini lebih besar dari briket arang buatan jepang (60-80\%) dan Amerika (58\%), namun lebih rendah dari briket arang buatan Inggis (75\%) (Hendra dan Winarni, 2003). Kadar karbon tidak dipersyaratkan dalam SNI 01-6235-2000.

Berdasarkan perhitungan sidik ragam, semua perlakuan dan interaksinya berpengaruh sangat nyata terhadap kadar karbon yang dihasilkan. Dari uji regresi ada kecenderungan bahwa makin tinggi suhu $\left(X_{1}\right)$, maka kadar karbon makin tinggi dan makin lama waktu pengarangan $\left(\mathrm{X}_{2}\right)$, kadar karbon makin rendah seperti terlihat pada Tabel 2. Menurut Hambali (2008), dalam proses pengarangan atau pirolisis pada suhu $200^{\circ} \mathrm{C}$ akan terjadi dekomposisi sellulosa dan akan berakhir pada suhu 300$350^{\circ} \mathrm{C}$. Kondisi ini akan terjadi dua tahap yaitu tahap pertama reaksi hidrolisis menghasilkan glukosa dan tahap kedua merupakan reaksi yang menghasilkan turunannya bersama dengan air dan sejumlah kecil fluran dan fenol.

Pada suhu $300-350^{\circ} \mathrm{C}$ lignin juga mulai mengalami dekomposisi dan berakhir pada suhu $400-450^{\circ} \mathrm{C}$. Proses pengarangan pada suhu $500-1000^{\circ} \mathrm{C}$ merupakan pemurnian arang. Pada proses pirolisis ini dihasilkan tiga macam pengulangan produk yaitu gas $\mathrm{CO}_{2}, \mathrm{CO}, \mathrm{CH}_{4}, \mathrm{H}_{2}, \mathrm{HCl}$, distilat (asap dan tar) dan residu berupa karbon (Tahir, 1992).

Dari uji BNJ menunjukkan bahwa tidak semua perlakuan dan interaksinya memberikan perbedaan yang nyata terhadap kadar karbon seperti ditampilkan pada Tabel 4. Sebagai contoh adalah suhu pengarangan $500^{\circ} \mathrm{C}$ dengan waktu pengarangan 3 jam (a2b2) sebesar $69,51 \%$ tidak memberikan perbedaan yang nyata terhadap kadar karbon yang dihasilkan pada suhu pengarangan $500^{\circ} \mathrm{C}$ dengan waktu pengarangan 2 jam (a2b1) sebesar $69,13 \%$. Menurut Djatmiko (1991), meningkatnya suhu dan waktu dalam proses karbonisasi, maka $\mathrm{CO}_{2}$ makin berkurang, sedangkan gas $\mathrm{CO}, \mathrm{CH}_{4}$ dan $\mathrm{H}$ semakin bertambah.

\section{Kadar zat terbang}

Kadar zat terbang briket arang tempurung kelapa sawit yang dihasilkan berkisar antara 18,31-39,03\% seperti ditampilkan pada Tabel 4 .

Tabel4. Hasil analisis kadar zat terbang, kadar sulfur dan nilai kalor

\begin{tabular}{|c|c|c|c|c|}
\hline \multirow{2}{*}{$\begin{array}{c}\text { Suhu } \\
\left({ }^{\circ} \mathrm{C}\right)\end{array}$} & \multirow{2}{*}{$\begin{array}{c}\text { Waktu } \\
\text { (jam) }\end{array}$} & \multicolumn{3}{|c|}{ Hasil Analisis } \\
\cline { 3 - 5 } & $\begin{array}{c}\text { Kadar zat } \\
\text { Terbang }(\%)\end{array}$ & $\begin{array}{c}\text { Kadar sulfur } \\
(\%))\end{array}$ & $\begin{array}{c}\text { Nilai kalor } \\
(\mathrm{kal} / \mathrm{g}))\end{array}$ \\
\hline 400 & 2 & 33,19 & Negatif & 6486,51 \\
400 & 3 & 35,44 & Negatif & 6476,58 \\
400 & 4 & 39,03 & Negatif & 6199,28 \\
\hline 500 & 2 & 21,57 & Negatif & 6488,36 \\
500 & 3 & 21,88 & Negatif & 6307,37 \\
500 & 4 & 31,11 & Negatif & 6232,99 \\
\hline 600 & 2 & 18,31 & Negatif & 7021,76 \\
600 & 3 & 25,64 & Negatif & 6615,78 \\
600 & 4 & 20,91 & Negatif & 6639,45 \\
\hline
\end{tabular}

Kadar zat terbang lebih tinggi dibandingkan kadar zat terbang briket arang buatan Jepang (15-30\%), Amerika (19$28 \%$ ), Inggis $(16,40 \%)$, dan persyaratan kadar zat terbang briket arang kayu dalam SNI 01-6235-2000, yaitu maksimum 15\%. Kadar zat terbang yang tertinggi $(39,03 \%)$ dihasilkan dari tempurung kelapa sawit yang diarangkan pada suhu $400^{\circ} \mathrm{C}$ dengan waktu pengarangan 4 jam dan kadar zat terbang yang terendah $(18,31 \%)$ diperoleh pada tempurung kelapa sawit yang diarangkan pada suhu $600^{\circ} \mathrm{C}$ dengan waktu 2 jam. Hendra dan Pari (2000), mengemukakan kadar zat terbang yang tinggi akan menimbulkan asap yang lebih banyak pada saat briket arang dinyalakan karena adanya reaksi antara karbon monoksida dengan turunan alkohol yang ada pada arang. 
Berdasarkan perhitungan sidik ragam, semua perlakuan dan interaksinya berpengaruh sangat nyata terhadap kadar zat terbang. Dari uji regresi, ada kecenderungan makin tinggi suhu, maka kadar zat terbang makin rendah dan makin lama waktu pengarangan, maka kadar zat terbang makin bertambah seperti tertera pada Tabel 2 .

Hasil uji BNJ seperti pada Tabel 5 menunjukkan bahwa tidak semua perlakuan dan interaksinya menyebabkan perbedaan yang nyata terhadap kadar zat terbang. Sebagai contoh adalah perlakuan suhu pengarangan $500^{\circ} \mathrm{C}$ dengan waktu pengarangan 3 jam (a2b3) diperoleh kadar zat terbang $21,88 \%$. Hal ini tidak memberikan perbedaan yang nyata terhadap kadar zat terbang yang dihasilkan pada suhu pengarangan $500^{\circ} \mathrm{C}$ dengan waktu pengarangan 2 jam (a2b1) yaitu 21,57\%.

Tabel 5. Hasil uji BNJ (beda nyata jujur) briket arang tempurung kelapa sawit

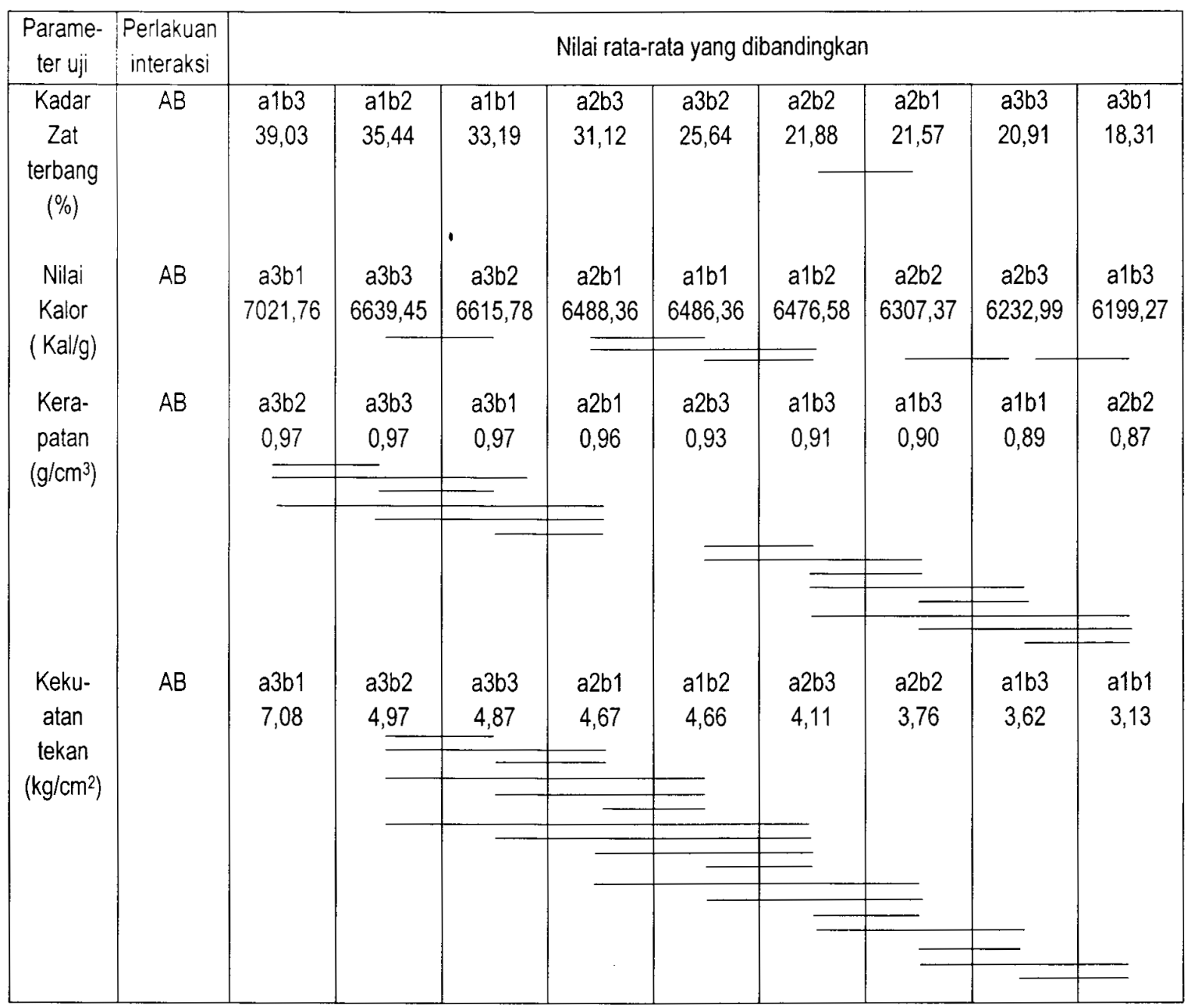

Keterangan: $\mathrm{AB}$ : Interaksi antara suhu dengan waktu pengarangan

Tidak berbeda nyata

\section{Kadar sulfur}

Hasil analisa kadar sulfur briket arang tempurung kelapa sawit untuk semua perlakuan suhu dan waktu pengarangan tempurung kelapa sawit adalah negatif seperti pada Tabel 4. Hal ini menunjukkan bahwa briket arang tempurung kelapa sawit tidak menimbulkan dampak pencemaran gas sulfur bila digunakan untuk bahan bakar keperluan rumah tangga. Persyaratan kualitas briket arang buatan Jepang, Amerika, Inggis dan SNI 01-6235-2000 tidak mempersyaratkan kadar sulfur. 


\section{Nilai kalor}

Nilai kalor briket arang tempurung kelapa sawit yang dihasilkan berkisar antara 6199,28-7021,76 kal/g. Data semua perlakuan dapat dilihat pada Tabel 4. Nilai ini lebih besar dibandingkan nilai kalor briket arang buatan Jepang (6000-7000 kal/g), Amerika (6200 kal/g) dan persyaratan dalam SNI 01-6235-2000 (minimum 5000 $\mathrm{kal} / \mathrm{g})$.

Berdasarkan perhitungan sidik ragam semua perlakuan dan interaksinya berpengaruh sangat nyata terhadap nilai kalor. Nilai kalor yang terbesar adalah $7021,76 \mathrm{kal} / \mathrm{g}$ diperoleh dari tempurung kelapa sawit yang diarangkan pada suhu $600^{\circ} \mathrm{C}$ selama 2 jam dan nilai kalor yang terendah adalah 6199,28 kal/g dihasilkan oleh tempurung kelapa sawit yang diarangkan pada suhu $400^{\circ} \mathrm{C}$ selama 4 jam. Dari uji regresi ada kecenderungan makin tinggi suhu pengarangan, maka nilai kalor makin tinggi seperti ditampilkan pada Tabel 2. Kondisi ini disebabkan karena proses pengarangan makin sempurna. Sudrajat (1982), mengemukakan dalam proses pengarangan semakin sempurna proses pengarangan, maka semakin tinggi nilai kalornya.

Penambahan waktu pengarangan ada kemungkinan menyebabkan terjadi penurunan nilai kalor seperti uji regresi pada Tabel 2. Hasil uji BNJ menunjukkan tidak semua perlakuan dan interaksinya memberikan perbedaan yang nyata terhadap nilai kalor seperti ditampilkan pada Tabel 5. Sebagai contoh adalah suhu pengarangan $600^{\circ} \mathrm{C}$ dengan waktu 4 jam adalah sebesar $6639,45 \mathrm{kal} / \mathrm{g}$ tidak memberikan perbedaan yang nyata terhadap nilai kalor yang dihasilkan pada suhu pengarangan $600^{\circ} \mathrm{C}$ dengan waktu 3 jam sebesar $6615,78 \mathrm{kal} / \mathrm{g}$. Yuliza (2013) melaporkan bahwa nilai kalor juga dipengaruhi oleh kadar air dan kadar abu yang ada dalam briket arang, semakin rendah kadar air dan kadar abu dalam briket arang maka akan meningkatkan nilai kalor briket arang yang dihasilkan.

\section{Kerapatan}

Nilai kerapatan briket arang tempurung kelapa sawit yang dihasilkan berkisar antara
$0,88-0,97 \mathrm{~g} / \mathrm{cm}^{3}$ seperti pada Tabel 6 . Nilai ini lebih kecil dari persyaratan briket arang buatan Jepang $\left(1,0-1,2 \mathrm{~g} / \mathrm{cm}^{3}\right)$ dan Amerika $\left(1,0 \mathrm{~g} / \mathrm{cm}^{3}\right)$, dan lebih besar dari persyaratan briket arang buatan Inggis $\left(1,48 \mathrm{~g} / \mathrm{cm}^{3}\right)$. Untuk briket arang kayu dalam SNI 01-62352000 nilai kerapatan tidak dipersyaratkan.

Berdasarkan perhitungan sidik ragam, semua perlakuan dan interaksinya berpengaruh sangat nyata terhadap kerapatan. Nilai kerapatan yang terbesar $\left(0,97 \mathrm{~g} / \mathrm{cm}^{3}\right)$ diperoleh dari tempurung kelapa sawit yang diarangkan pada suhu $600^{\circ} \mathrm{C}$ selama $2-4$ jam dan nilai yang terendah $\left(0,88 \mathrm{~g} / \mathrm{cm}^{3}\right)$ dihasilkan oleh tempurung kelapa sawit yang diarangkan pada suhu $500^{\circ} \mathrm{C}$ dengan waktru 3 jam. Dari hasil uji regresi ada kecenderungan makin tinggi suhu pengarangan, maka nilai kerapatan makin tinggi, dan makin lama waktu pengarangan, maka nilai kerapatan makin rendah seperti pada Tabel 2 .

Tabel6. Hasil analisis kerapatan dan kekuatan tekan

\begin{tabular}{|c|c|c|c|}
\hline \multirow{2}{*}{$\begin{array}{c}\text { Suhu } \\
\left({ }^{\circ} \mathrm{C}\right)\end{array}$} & \multirow{2}{*}{$\begin{array}{c}\text { Waktu } \\
(\text { jam })\end{array}$} & \multicolumn{2}{|c|}{ Hasil Analisis } \\
\cline { 3 - 4 } & & $\begin{array}{c}\text { Kerapatan } \\
\left(\mathrm{gr} / \mathrm{cm}^{3}\right)\end{array}$ & $\begin{array}{c}\text { Kuat tekan } \\
\left(\mathrm{kg} / \mathrm{cm}^{2}\right)\end{array}$ \\
\hline 400 & 2 & 0,89 & 3,13 \\
400 & 3 & 0,91 & 4,66 \\
400 & 4 & 0,90 & 3,62 \\
\hline 500 & 2 & 0,96 & 4,67 \\
500 & 3 & 0.88 & 3,76 \\
500 & 4 & 0.92 & 4,11 \\
\hline 600 & 2 & 0,97 & 7,08 \\
600 & 3 & 0,97 & 4,97 \\
600 & 4 & 0,97 & 4,87 \\
\hline
\end{tabular}

Berdasarkan uji BNJ yang ditampilkan pada Tabel 5 , tidak semua perlakuan dan interaksinya memberikan perbedaan yang nyata terhadap nilai kerapatan. Sebagai contoh adalah suhu pengarangan $600^{\circ} \mathrm{C}$ dengan waktu 3 jam sebesar 0,97 $\mathrm{g} / \mathrm{cm}^{3}$ tidak memberikan perbedaan yang nyata terhadap nilai kerapatan yang dihasilkan oleh suhu pengarangan $600^{\circ} \mathrm{C}$ dengan waktu 4 jam sebesar $0,97 \mathrm{~g} / \mathrm{cm}^{3}$.

Nilai kerapatan briket arang tidak hanya ditentukan oleh penggunaan bahan baku yang mempunyai berat jenis tinggi, tetapi juga ditentukan oleh konsentrasi perekat dan tekanan pengempaan. Apabila konsentrasi perekat yang diberikan makin 
tinggi, maka akan menghasilkan kerapatan briket arang yang tinggi pula. Hal ini disebabkan semakin tinggi jumlah perekat maka akan semakin banyak perekat yang mengisi pori-pori briket arang sehingga mengakibatkan ikatan antara perekat dengan serbuk arang akan semakin baik karena partikel-partikel arang dapat menyatu, solid dan lebih rapat satu sama lain (Bahri, 2008).

\section{Kekuatan Tekan}

Kekuatan tekan briket arang tempurung kelapa sawit yang dihasilkan berkisar antara $3,13-7,08 \mathrm{~kg} / \mathrm{cm}^{2}$ ditampilkan pada Tabel 6 . Kekuatan tekan yang tertinggi $\left(7,08 \mathrm{~kg} / \mathrm{cm}^{2}\right)$ diperoleh dari tempurung kelapa sawit yang diarangkan pada suhu $600^{\circ} \mathrm{C}$ selama 2 jam dan kekuatan yang terendah $\left(3,13 \mathrm{~kg} / \mathrm{cm}^{2}\right)$ dihasilkan dari tempurung kelapa sawit yang diarangkan pada suhu $400^{\circ} \mathrm{C}$ selama 2 jam. Nilai kekuatan tekan ini lebih kecil dari persyaratan briket arang buatan Jepang $\left(60-65 \mathrm{~kg} / \mathrm{cm}^{2}\right)$, Amerika $\left(62 \mathrm{~kg} / \mathrm{cm}^{2}\right)$ dan Inggis $\left(12,7 \mathrm{~kg} / \mathrm{cm}^{2}\right)$. Standar Nasional Indonesia 01-6235-2000 tidak mempersyaratkan nilai kekuatan tekan briket arang. Menurut Priyo Waspodo (2009), kekuatan tekan briket arang yang besar dapat mengantisipasi untuk mencegah kerusakan dalam pengepakan selama proses transportasi dan penyimpanan.

Berdasarkan perhitungan sidik ragam, semua perlakuan dan interaksinya berpengaruh sangat nyata terhadap kekuatan tekan yang dihasilkan. Dari uji regresi yang ditampilkan pada Tabel 2, ada kecenderungan bahwa makin tinggi suhu pengarangan, maka makin tinggi kekuatan tekan dan makin lama waktu pengarangan, maka makin rendah kekuatan tekan briket arang yang dihasilkan. Semakin rendah nilai kekuatan tekan, maka semakin rendah nilai kalor briket arang. Berdasarkan uji BNJ pada Tabel 6 menunjukkan tidak semua perlakuan dan interaksinya memberikan perbedaan yang nyata terhadap kekuatan tekan. Sebagai contoh adalah perlakuan suhu pengarangan $600^{\circ} \mathrm{C}$ dengan waktu 3 jam (a3b2) sebesar $4,97 \mathrm{~kg} / \mathrm{cm}^{2}$ tidak memberikan perbedaan yang nyata terhadap nilai kekuatan tekan yang dihasilkan pada suhu pengarangan $600^{\circ} \mathrm{C}$ dengan waktu 4 jam (a3b3) sebesar 4,87 $\mathrm{kg} / \mathrm{cm}^{2}$.

\section{KESIMPULAN}

Tempurung kelapa sawit yang diarangkan pada suhu $400-600^{\circ} \mathrm{C}$ selama 24 jam menghasilkan kualitas briket arang dengan karakteristik kadar air 2,45-3,68\%; kadar abu 5,15-7,40\%; kadar karbon 52,24$72,93 \%$; kadar zat terbang 18,31-39,03\%; kadar sulfur negatif; nilai kalor 6199,28$7021,76 \mathrm{kal} / \mathrm{g}$; kerapatan 0,88-0,97 $\mathrm{g} / \mathrm{cm}^{3}$ dan kekuatan tekan $3,13-7,08 \mathrm{~kg} / \mathrm{cm}^{2}$. Suhu dan waktu pengarangan berpengaruh sangat nyata terhadap kualitas briket arang tempurung kelapa sawit yang dihasilkan. Ditinjau dari nilai kalornya, tempurung kelapa sawit yang diarangkan pada suhu $600^{\circ} \mathrm{C}$ selama 2 jam menghasilkan kualitas briket arang yang terbaik dengan kadar air $2,92 \%$; kadar abu 5,83\%; kadar karbon $72,93 \%$; kadar zat terbang 18,31\%; kadar sulfur negatif; nilai kalor $7021,76 \mathrm{kal} / \mathrm{g}$; kerapatan $0,97 \mathrm{~g} / \mathrm{cm}^{3}$ dan kekuatan tekan $7,08 \mathrm{~kg} / \mathrm{cm}^{2}$. Produk briket arang ini memenuhi syarat mutu briket arang kayu sesuai SNI 01-6235-2000.

\section{DAFTAR PUSTAKA}

Badan Standardisasi Nasional. 1994. Analisis kadar abu contoh batu bara. Standar Nasional Indonesia 13-34781994. Dewan Standardisasi Nasional. Jakarta.

Badan Standardisasi Nasional. 1994. Analisis kadar belerang contoh batu bara. Standar Nasional Indonesia 133481-1994. Dewan Standar Nasional. Jakarta.

Badan Standardisasi Nasional. 2000. Briket arang kayu. Standar Nasional Indonesia 01-6235-2000. Dewan Standardisasi Nasional. Jakarta.

Bahri, S. 2008. Pemanfaatan limbah industri pengolahan kayu untuk pembuatan briket arang dalam mengurangi pencemaran lingkungan di Nangroe Aceh Darussalam. Tesis, USU eRepository. 
Direktorat Jenderal Perkebunan. 2012. Produksi, luas areal dan produktivitas kelapa sawit di Indonesia. Kementerian Pertanian. Jakarta.

Djatmiko, B. 1991. Arang pengolahan dan kegunaannya. Jurusan Teknologi Pertanian. Fakultas Teknologi Pertanian. IPB. Bogor.

Fauzi. YW., dan Satyawibawa, I. 2002. Pemanfaatan hasil dan limbah analisis usaha dan pemasaran kelapa sawit seri agibisnis. Penebar Swadaya. Jakarta.

Hendra. D., dan Pari, G. 2009. Penyempurnaan teknologi pengolahan arang. Laporan Hasil Penelitian. Pusat Penelitian Hasil Hutan. Badan Penelitian dan Pengembangan Kehutanan. Bogor.

Hendra, D. dan Winarni. 2003. Sifat fisik dan kimia briket arang campuran limbah kayu gergajian dan sebetan kayu. Buletin Penelitian Hasil Hutan 21(3): 211-226. Pusat Penelitian dan Pengembangan Hasil Hutan. Bogor.

Hambali, F., Mujalipah, S. dan Haloman, A. 2008. Teknologi bioenergi. Agomedia Pustaka. Jakarta.

Mahdie, M., F. 2010. Briket arang dari limbah arang PT. Citra Prima Utama Banjarbaru. Jurnal Hutan Tropis Vol. 11 No. 29: 1-8. Universitas Lambung Mangkurat, Banjarbaru.

Martynis, M., Sundari, E. dan Sari, E. 2012. Pembuatan biobriket dari limbah cangkang kakao. Jurnal Litbang Industri Vol. 2 No. 1: 31-37. Baristand Industri Padang.

Nurwati, H. 2004. Sifat fisik dan mekanik kayu. Pusat Penelitian Teknologi Hasil Hutan. Badan Penelitian dan Pengembangan Kehutanan. Departemen Kehutanan. Bogor.
Nurhayati, T. dan Adalina, Y. 2007. Analisis teknis dan finansial produksi arang dan cuka kayu dari limbah industri penggergajian dan pemanfaatannya. Jurnal Penelitian Hasil Hutan 27(1): 437-380. Badan penelitian dan Pengembangan Kehutanan. Bogor

Priyo Waspodo. HGP dan Yang Yang. 2009. Pengaruh perubahan rancangan anglo dan berat jenis briket arang terhadap peningkatan efisiensi penggunaan panas. Jurnal Warta Industri Hasil Pertanian 26 (1): 1-11. Bogor.

Purwanto. D. 2011. Arang dari limbah tempurung kelapa sawit. Jurnal Penelitian Hasil Hutan 29(1): 57-66. $\mathrm{B}$ a d a $\mathrm{n}$ e n e litian d a n Pengembangan Kehutanan. Bogor.

Raharjo, S. 2013. Pembuatan briket bioarang dari limbah abu ketel, jarak dan gliserin. Traksi Vol. 13 No. 1: 1932. Unimus, Semarang.

Sudrajat. 1982. Produksi arang dan briket a ra n g s e r t a pros pe k pengusahaannya. Pusat Penelitian dan Pengembangan Kehutanan. Departemen Pertanian. Bogor.

Sudjana. 1985. Desain dan analisis eksperimen. Edisi 5. Tarsito. Bandung.

Tahir. 1992. Pengambilan asap cair secara destilasi kering pada proses pembuatan karbon aktif. FMIPA UGM. Yogyakarta.

Wijayanti, D.S. 2009. Karakteristik briket arang dari serbuk gergaji dengan penambahan arang cangkang kelapa sawit. Departemen Kehutanan, Fakultas Pertanian, Universitas Sumatera Utara, Medan.

Yuliza, N., Nazir, N. dan Djalal, M. 2013. Pengaruh komposisi arang sekam padi dan arang kulit biji jarak pagar terhadap mutu briket arang. Jurnal Litbang Industri Vol. 3 No. 1: 21-30. Baristand Industri Padang. 